\title{
Szymon OPANIA*
}

\section{ANALIZA FUNKCJONALNA I KOMPOZYCYJNA KONCEPCJI REWITALIZACJI STREFY NOWEGO CENTRUM ŁODZI}

\section{A FUNCTIONAL AND COMPOSITIONAL ANALYSIS OF THE CONCEPT OF REVITALISATION OF THE NEW CENTER ZONE IN LÓDŹ}

\author{
Nr DOI: $10.25167 / \mathrm{sm} 2017.026 .05 \quad$ s. $65-82$
}

\begin{abstract}
ABSTRAKT: Analizując współczesne tendencje przekształceń miast, można zauważyć wyróżniające się dwie grupy projektów. Jedna z nich opiera się na realizowaniu postulatów zrównoważonego rozwoju w budowie miast, stawiając sobie za cel istotne dla miasta priorytety, natomiast druga zakłada realizację dużych zadań infrastrukturalnych, polepszających funkcjonowanie wybranych obszarów miast. Wielość tych koncepcji powoduje, że Philip Jodido postrzega lata 90. ubiegłego wieku właśnie przez pryzmat rozwoju komunikacji i systemów komunikacji, które stały się istotnym czynnikiem rozwoju, wspieranym przez administracje rządowe i samorządowe w większości państw europejskich. Konsekwencją tego był wzrost znaczenia i jakości projektów urbanistyczno-architektonicznych dotyczących tej kategorii.

W tej drugiej grupie obok projektu Euralille, autorstwa Rema Koolhaasa, łączącego Paryż i Londyn trasą TGV, można wymienić koncepcję Nowego Centrum Łodzi realizowaną w okolicach dworca kolejowego Łódź Fabryczna oraz Elektrociepłowni I jako centrum przesiadkowe i kulturalne miasta.

Celem artykułu jest analiza funkcji oraz kompozycji koncepcji rewitalizacji tego obszaru, począwszy od masterplanu Roba Kriera z 2007 r. po projekt miejscowego planu zagospodarowania przestrzennego dla tej części miasta Łodzi opracowany przez Miejską Pracownię Urbanistyczną z Łodzi z roku 2014.
\end{abstract}

SŁOWA KLUCZOWE: przekształcenia struktur miejskich, kompozycja urbanistyczna, rewitalizacja

ABSTRACT: Analyzing contemporary tendencies of cities transformations, it is possible to notice two groups of projects standing out: one of them is based on carrying out demands of the sustainable development of cities under construction, setting their priorities as an important goal, whereas the other one assumes the accomplishment of great infrastructural tasks which are designed to improve functioning of chosen areas of cities. The multitude of these concepts caused Philip Jodido to perceive the 1990s through the prism of development of transport and communication systems, which became a significant factor in the development at all, supported by administrations of central and local governments of most European countries. As a consequence, there was a growth in the importance and quality of urban-architectural projects concerning this category.

In the second group, beside Rem Koolhaas's Euralille project, linking Paris and London with TGV route, it is possible to mention the concept of Łódźs New Centre, carried out in the environs of Łódź Fabryczna railway station and Elektrocieptownia I, as a transfer point and a cultural centre of the city.

* Politechnika Śląska, Wydział Architektury, Katedra Urbanistyki i Planowania Przestrzennego, e-mail: szymon.opania@polsl.pl. 
The main purpose of the article is to analyze the functional and compositional solutions used in revitalization of this area, starting with Rob Krier's masterplan of 2007 and ending with the zoning project drawn up for this part of Łódź by the Municipal Urban Planning Studio of Łódź in 2014.

KEY WORDS: transformation of urban structures, urban composition, revitalization

\section{Wprowadzenie}

Łódź jest miastem o szczególnym nawarstwieniu barier przestrzennych i progów rozwojowych. Jest to konsekwencją upadku form zagospodarowania przestrzennego, które onegdaj stanowiły o znaczeniu i randze miasta. Szczególnie było to widoczne w obszarze otoczenia dworca kolejowego Łódź Fabryczna, dla którego w 2007 r. przyjęto uchwałę w sprawie przyjęcia Programu Nowe Centrum Łodzi zawierającego się pomiędzy ulicami: J. Tuwima, G. Narutowicza, H. Sienkiewicza oraz S. Kopcińskiego (rysunek 1). Wypracowane w ramach programu projekty miały się stać podstawą do realizacji polityki przestrzennej dla tej części miasta realizowanej przez władze miasta Łódź.

Obszar ten wydaje się miejscem istotnym dla rozwoju miasta ze względu na zarówno swoją lokalizację, jak i historyczne znaczenie. Związane jest ono z latami świetności w XIX w., widocznej w zwartej zabudowie i lokalizacji węzła przeładunkowego na dworcu kolejowym. Niestety z powodu istniejących problemów ekonomicznych, społecznych i infrastrukturalnych miasta również ta okolica sukcesywnie traciła swój pierwotny charakter. Symbolem tych przemian stał się zaniedbany dworzec Łódź Fabryczna (rysunek 2), którego ślepe zakończenie uniemożliwiało zdyskontowanie centralnego położenia. Otaczające stację hektary terenów kolejowych i przemysłowych dopełniały obrazu przestrzeni martwej i pozbawionej perspektyw.

\section{Przyjęta metoda analizy}

Metoda analizy opiera się na charakterystyce wykonanej na podstawie dostępnych dokumentów i syntezie zawartych w nich istotnych elementów w zakresie rozwiązań funkcjonalnych i formalnych, z punktu widzenia celu, opracowań i dokumentów.

Ze względu na różny charakter opracowań urbanistycznych i planistycznych, tj. grafikę, zakres merytoryczny i formalny, dla założonych celów wykonano schematy graficzne syntetyzujące istotne rozwiązania przestrzenne i pozwalające porównać rozwiązania formalne projektów. Zaznaczono na nich:

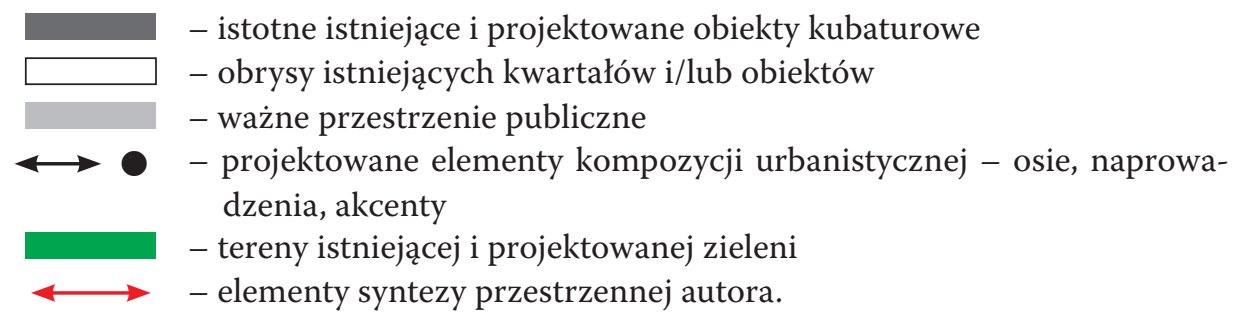




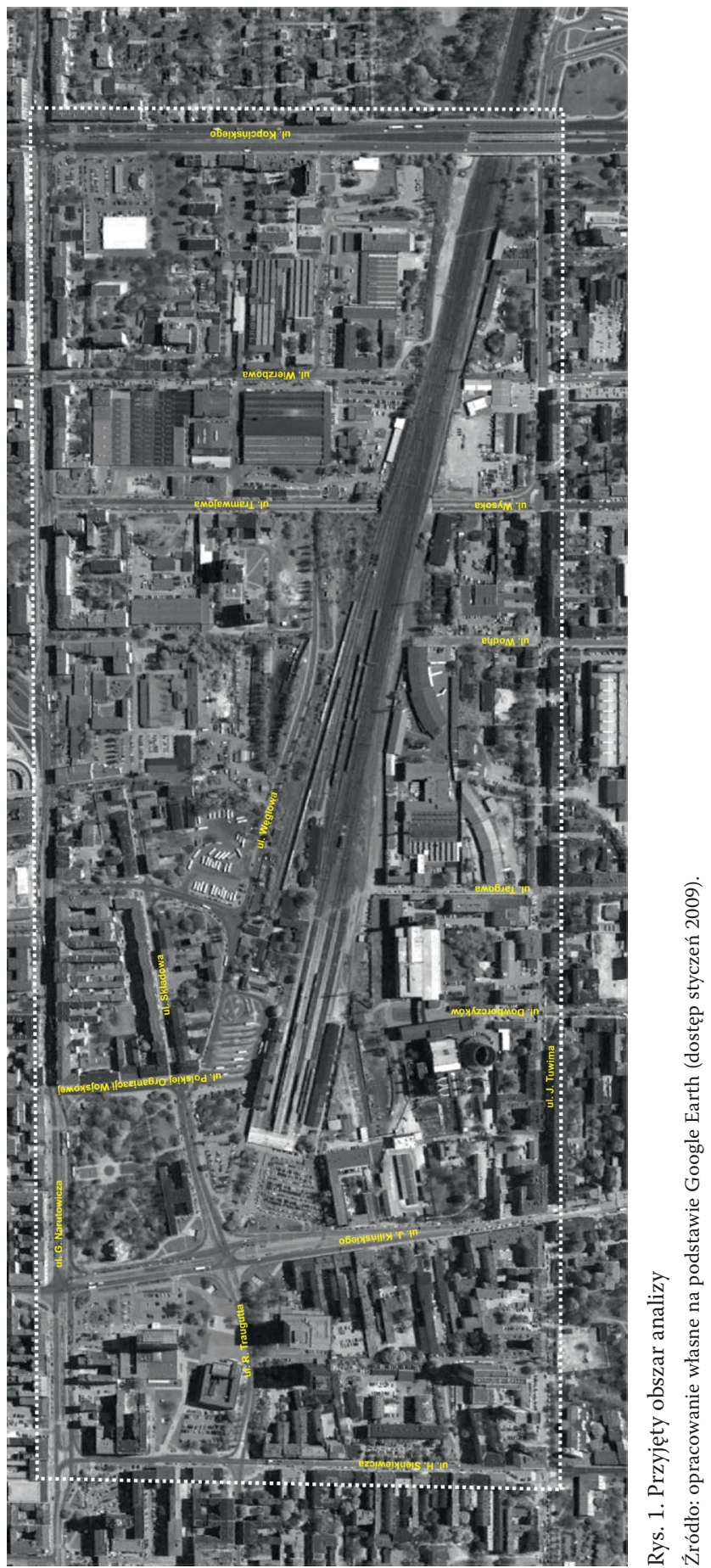




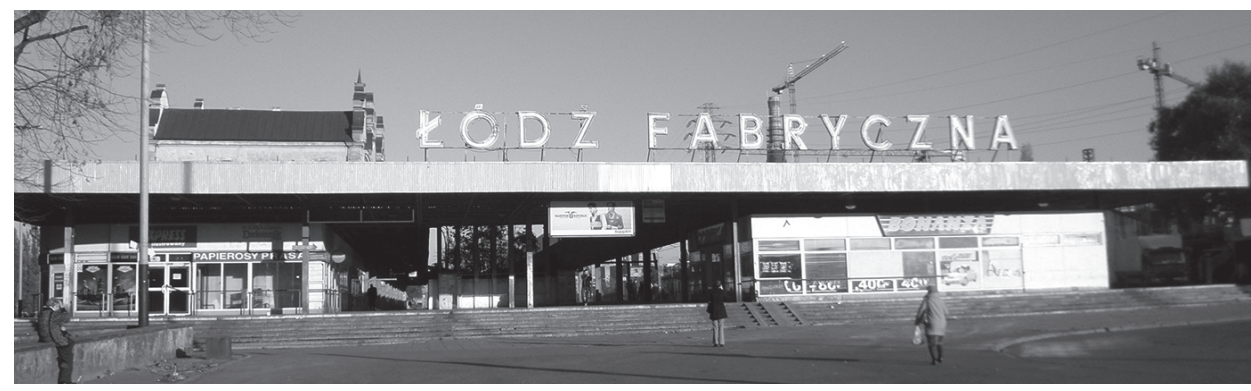

Rys. 2. Dworzec Łódź Fabryczna, stan z 2011 r.

Źródło: fot. S. Opania.

\section{Struktura przestrzenna - stan istniejący}

W obszarze objętym opracowaniem zauważalne były istotne ze względów kompozycji urbanistycznej elementy istniejącej struktury przestrzennej, mające wpływ na późniejsze rozwiązania urbanistyczne i planistyczne. Według autora należały do nich (rysunek 3):

- oś ciągu komunikacji kolejowej z dworcem Łódź Fabryczna,

- oś parku St. Moniuszki,

- osie ulic: J. Kilińskiego, Polskiej Organizacji Wojskowej, Dowborczyków, W. Knychalskiego, W. Lidleya, Wodnej, Tramwajowej i Wierzbowej.

\section{Uproszczony Lokalny Program Rewitalizacji wybranych terenów śródmiejskich oraz pofabrycznych Łodzi na lata 2004-2013}

W 2004 r. w Uproszczonym Lokalnym Programie Rewitalizacji (LPR) wskazano, iż Łódź jest miastem o szczególnym charakterze z uwagi na skalę i typ barier, jakie w nim występują. Największą z nich jest bariera strukturalna wynikająca z niedopasowania struktury przestrzennej oraz zużytych technologicznie i społecznie form zagospodarowania kubaturowego, nieprzystających do współczesnych funkcji metropolitalnych. Stąd w programie rewitalizacji określono strefy wzajemnego pozytywnego i negatywnego oddziaływania obszarów zdegradowanych, obszarów prosperujących, obszarów w transformacji i obszarów buforowych. Warunek ten był konieczny dla określenia minimalnej skali przekształceń gwarantującej samoistny i trwały rozwój każdego z rewitalizowanych fragmentów miasta.

Na podstawie przyjętych kryteriów wytypowano obszary węzłowe, których rewitalizacja będzie rzutowała bezpośrednio na jakość przestrzeni publicznej centrum i terenu decydującego o tożsamości Łodzi. Wśród nich wskazano obszar korytarza ulicy G. Narutowicza i przedpole dworca Fabrycznego. Jednak jego skala i amorficzna struktura oraz odczuwalna w opinii autorów programu potrzeba znacznych 


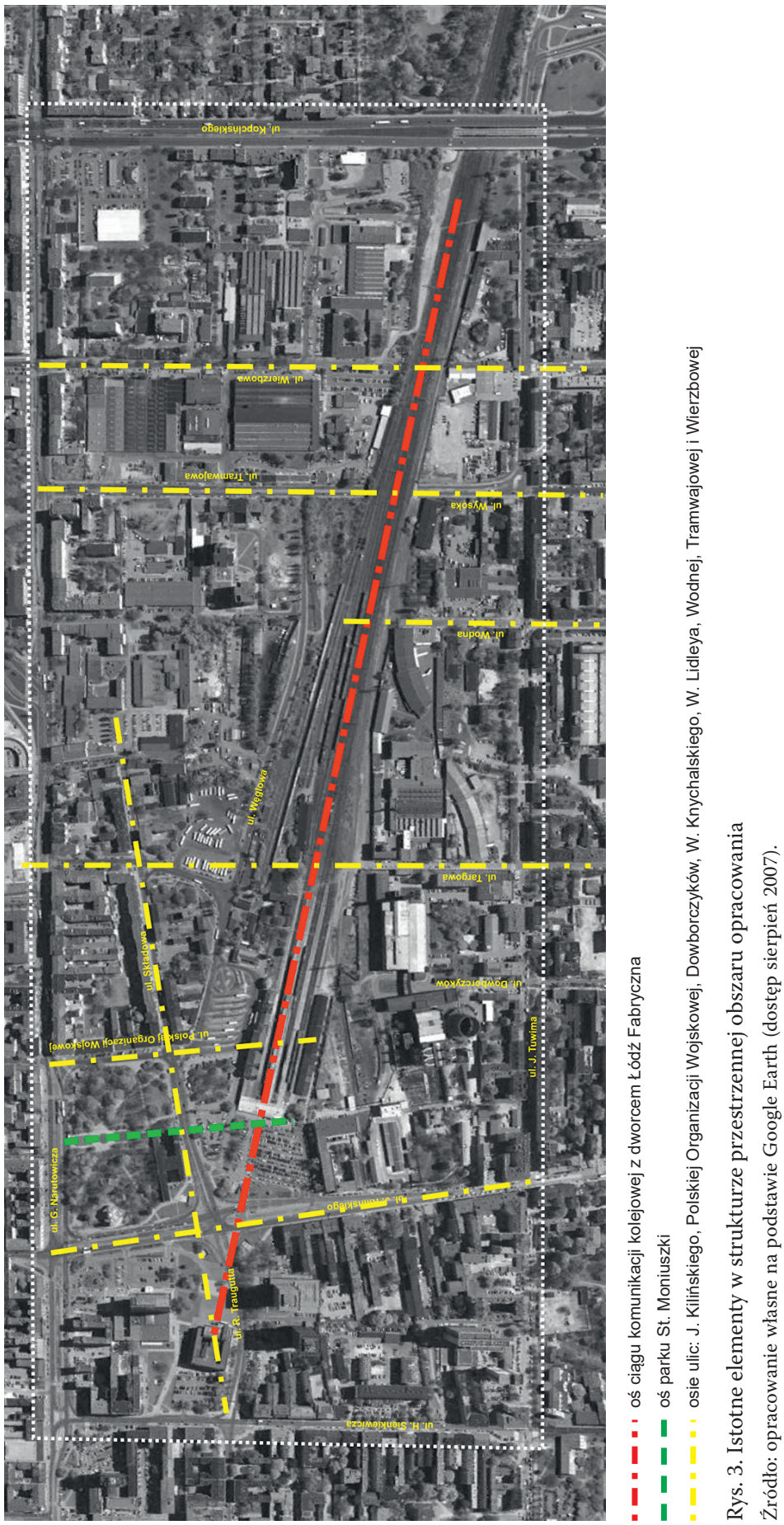


inwestycji negatywnie wpłynęły na wybór jego jako priorytetowego obszaru dla LPR. Ponadto nie była też zdefiniowana rola tego obszaru w układzie komunikacyjnym miasta i regionu.

Na podstawie kryterium lokalizacji w sąsiedztwie jak największej liczby obszarów wytypowanych jako priorytetowe obszar ten zakwalifikowano do działań na drugim etapie. Na tym etapie przewidziano działania charakteryzujące się znacznym udziałem elementu kreatywnego i niesprzecznego z potrzebami rozwoju węzła komunikacji szynowej. Jednocześnie obszar wymagał stworzenia strukturalnego powiązania terenów dworca z centrum miasta i reprezentacyjną przestrzenią publiczną oraz działań rewitalizacyjnych w obrębie przyległych kwartałów zachowanej tkanki miejskiej.

\section{Masterplan Roba Kriera - 2007 r.}

W 2006 r. David Lynch - reżyser, Andrzej Walczak - współwłaściciel Grupy Atlas, oraz Marek Żydowicz - dyrektor Międzynarodowego Festiwalu Filmowego Camerimage, założyli Fundację Sztuki Świata, której celem było otwarcie Centrum Sztuki Filmowej Davida Lyncha w zabytkowym budynku elektrowni w pobliżu dworca Łódź Fabryczna. Założyciele fundacji podkreślali, iż realizacja tej inwestycji w dawnej elektrociepłowni EC-1 może dać impuls do rewitalizacji otaczającego ją większego obszaru Śródmieścia. W celu przywrócenia dawnej świetności okolicom EC-1 oraz dworca Łódź Fabryczna i przystosowaniu tych terenów do pełnienia funkcji kulturalnych założyciele fundacji zwrócili się do luksemburskiego architekta i urbanisty Roba Kriera ${ }^{1}$, który sporządził masterplan obejmujący teren pomiędzy ulicami: Tuwima, Sienkiewicza, Narutowicza i nowo projektowaną.

Istotą założeń funkcjonalnych masterplanu Kriera stało się przeniesienie dworca Łódź Fabryczna pod ziemię i powstanie tzw. Rynku Fabrycznego, wokół którego zlokalizowane miały być: hala kongresowo-festiwalowa na 4 tys. miejsc, muzeum techniki, filia Muzeum Sztuki, hotele, luksusowe apartamenty, restauracje oraz puby (Krier, Kohl 2007).

Pierwszy, „odręczny” masterplan ewoluował w kierunku porządkowania przestrzeni z wykorzystaniem zasady klasycznej symetrii, charakterystycznej dla prac Kriera (Krier 1979), które widoczne jest w rozwiązaniach uwidocznionych na rysunku 4, m.in.:

- trapezowym rynku Kobro projektowanym na osi ul. Knychalskiego z centralnie zlokalizowanym akcentem przestrzennym dającym jednocześnie początek nowej osi przestrzeni publicznej pomiędzy planowanymi ulicami Żydowską i Polską;

\footnotetext{
${ }^{1}$ Rob Krier (ur. 1938) - luksemburski architekt, urbanista, planista, rzeźbiarz i niemieckojęzyczny publicysta. Jeden z głównych przedstawicieli współczesnej architektury konserwatywnej. W latach 70. był czołowym przedstawicielem postmodernizmu w architekturze, później, w latach 80., włączył się w powstały w USA ruch Nowego Urbanizmu i Nowego Tradycjonalizmu. Zyskał sławę, opracowując koncepcje rewitalizacji zdegradowanych obszarów: Berlina, Poczdamu, Stuttgartu czy Amsterdamu.
} 
- wytyczeniu w oparciu o oś ul. Polskiej Organizacji Wojskowej symetrycznej przestrzeni publicznej w formie placu, przed EC-1 zachód;

- wykorzystaniu komina chłodni kominowej jako zamknięcia kompozycyjnego i widokowego projektowanej ulicy z kierunku północnego zachodu;

- przełamaniu osi przestrzeni publicznej pomiędzy ulicami Polską i Żydowską w kierunku cerkwi św. Aleksandra Newskiego wraz z wyznaczeniem akcentu przestrzennego;

- akcentach przymykających park Moniuszki od strony południowej, zwieńczających po bokach przestrzeń publiczną zawartą pomiędzy ul. Polską i Żydowską;

- wytyczeniu linii zabudowy ul. Polskiej w oparciu o linię wychodzącą z punktu przebicia osi ul. Knychalskiego i linii zabudowy budynku EC-1 wschód;

- geometrycznym przedpolu przed budynkami BZWBK i Galerią Forum Fotografii;

- uzupełnieniu linii zabudowy wzdłuż ul. Kilińskiego w oparciu o istniejące budynki, w tym obiekt mieszczący Bibliotekę Główną Akademii Muzycznej im. G.K. Bacewiczów przy ul. Kilińskiego 79;

- wyznaczeniu dominant przestrzennych na przecięciach osi ul. Węglowej z osią kompozycyjną parku Moniuszki i z nowo projektowaną ulicą;

- powstaniu Małego Rynku z akcentem przestrzennym;

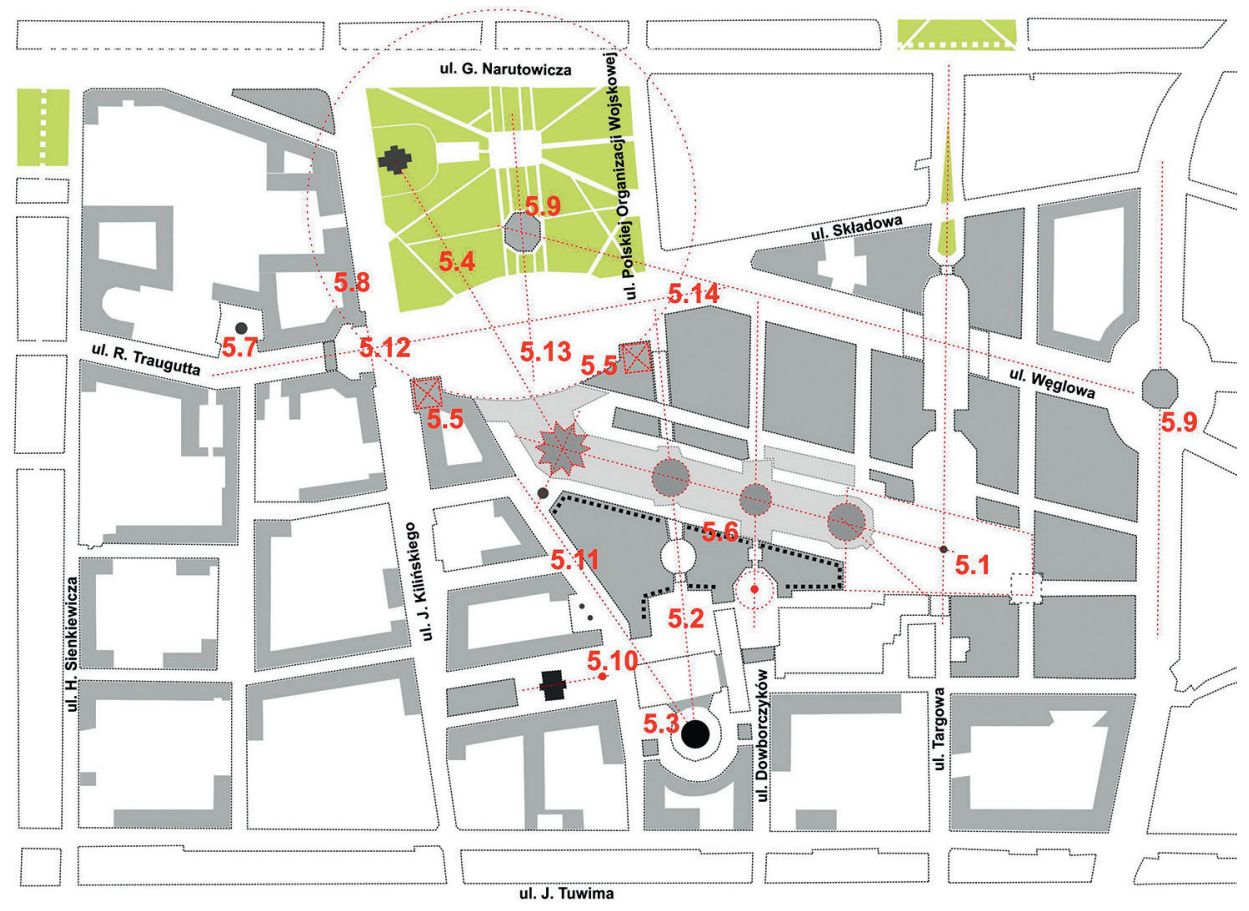

Rys. 4. Schemat graficzny masterplanu Roba Kriera

Źródło: opracowanie własne. 
- wykorzystaniu komina chłodni kominowej jako zamknięcia kompozycyjnego i widokowego projektowanej ulicy, biegnącej na kierunku północny zachód - południowy wschód;

- przymknięciu ul. gen. Traugutta z jednoczesnym otwarciem przestrzeni na plac przed parkiem Moniuszki;

- uzupełnieniu przestrzeni publicznej parku Moniuszki o geometryczny plac zbudowany na istniejącej osi parku (północ-południe) oraz nowo projektowanej (wschódzachód), wychodzącej z zamknięcia ul. Traugutta i prostopadłej do osi parku;

- wyznaczeniu linii zabudowy „otwarcia” na park równolegle do prostopadłej, nowo projektowanej osi przestrzeni publicznej „placu” Moniuszki.

\section{Program Nowe Centrum Lodzi - 2007 r.}

Impuls w postaci masterplanu Kriera doprowadził do uchwały Rady Miejskiej w Łodzi w sprawie przyjęcia Programu Nowe Centrum Łodzi. Programem objęto obszar ograniczony ulicami: Tuwima, Narutowicza, Sienkiewicza oraz Kopcińskiego, o łącznej powierzchni ok. 90 ha, a teren ten podzielony został na dwie strefy:

- strefa 1 (ok. 30 ha), w której miała dominować funkcja kulturalna, z zachowaniem funkcji pozwalających na całodobowe życie tego obszaru. Realizowane miały tu być projekty: rewitalizacji EC-1 i jej adaptacji na cele kulturalno-artystyczne, Specjalnej Strefy Kultury ze Specjalną Strefą Sztuki, rynek, Centrum Festiwalowe; miały również nastąpić przekształcenia związane z przebudową dworca Łódź Fabryczna wraz z jego otoczeniem;

- strefa 2 (ok. 60 ha), w której realizowane miały być przedsięwzięcia komercyjne związane z realizacją celu programu.

Celem programu było wykreowanie nowego obszaru funkcjonalnego centrum miasta poprzez:

- rewitalizację obszarów poprzemysłowych i kolejowych;

- wzmocnienie funkcji metropolitalnych i kulturalnych;

- zachowanie istotnych elementów tkanki urbanistycznej stanowiących o tożsamości i historii tego obszaru;

- stworzenie multimodalnego węzła komunikacyjnego (kolei wysokich prędkości, kolei regionalnej, komunikacji autobusowej oraz komunikacji miejskiej);

- stworzenie dostępnych, bezpiecznych i atrakcyjnych dla mieszkańców i turystów przestrzeni publicznych;

- stworzenie nowych przestrzeni do inwestowania (Uchwała Nr XVII/279/07... 2007).

Pomysł budowania Nowego Centrum Łodzi w Śródmieściu zaczął się od idei powstania rynku i schowania pod ziemię dworca kolejowego oraz autobusowego. Rynek oznaczał nowoczesną agorę żywego spotkania, która miałaby pełnić funkcje związane z realizacją imprez masowych, koncertów, pokazów czy happeningów. Założono prze- 
niesienie pod jego powierzchnię, we współpracy z PKP, dworca Fabrycznego z peronami. Przy rynku przewidziano lokalizację Specjalnej Strefy Kultury, która jako jedyna ze specjalnych stref ekonomicznych miała zawierać w sobie Specjalną Strefę Sztuki służącą przedstawianiu najistotniejszych dokonań artystycznych.

Nowe Centrum miało być realizowane w obszarze planowanych przecięć ulic: Niemieckiej, Rosyjskiej, Żydowskiej i Polskiej. Z punktu widzenia urbanistyki i socjologii miasta przecinające się ze sobą ulice miałyby wykreować nigdy nieistniejące wielokulturowe „nowe Stare Miasto”. Wyznaczając w dyspozycjach przestrzennych obszaru kilkadziesiąt jednakowych działek tak, aby nawiązać do początków Łodzi w XIX w., miasto symbolicznie zapraszało do ich zagospodarowania w sposób, który na stałe wpisze Nowe w Stare nie tylko swoją pasją, swoją dumą, ale także architekturą.

Od strony wschodniej rynek miało zamknąć Centrum Festiwalowo-Kongresowe (rysunek 5), planowana niezbędna w Łodzi hala. Centrum miało być miejscem, gdzie zagości Festiwal Camerimage oraz będą organizowane inne festiwale o randze międzynarodowej.

Pierzeję południową rynku miał zamknąć zespół obiektów zrewaloryzowanych po stuletniej elektrociepłowni EC-1. Rewitalizacja EC-1 i jej adaptacja na cele kulturalno-artystyczne zostały podzielone na trzy obszary oraz zlokalizowane w ich granicach budynki.

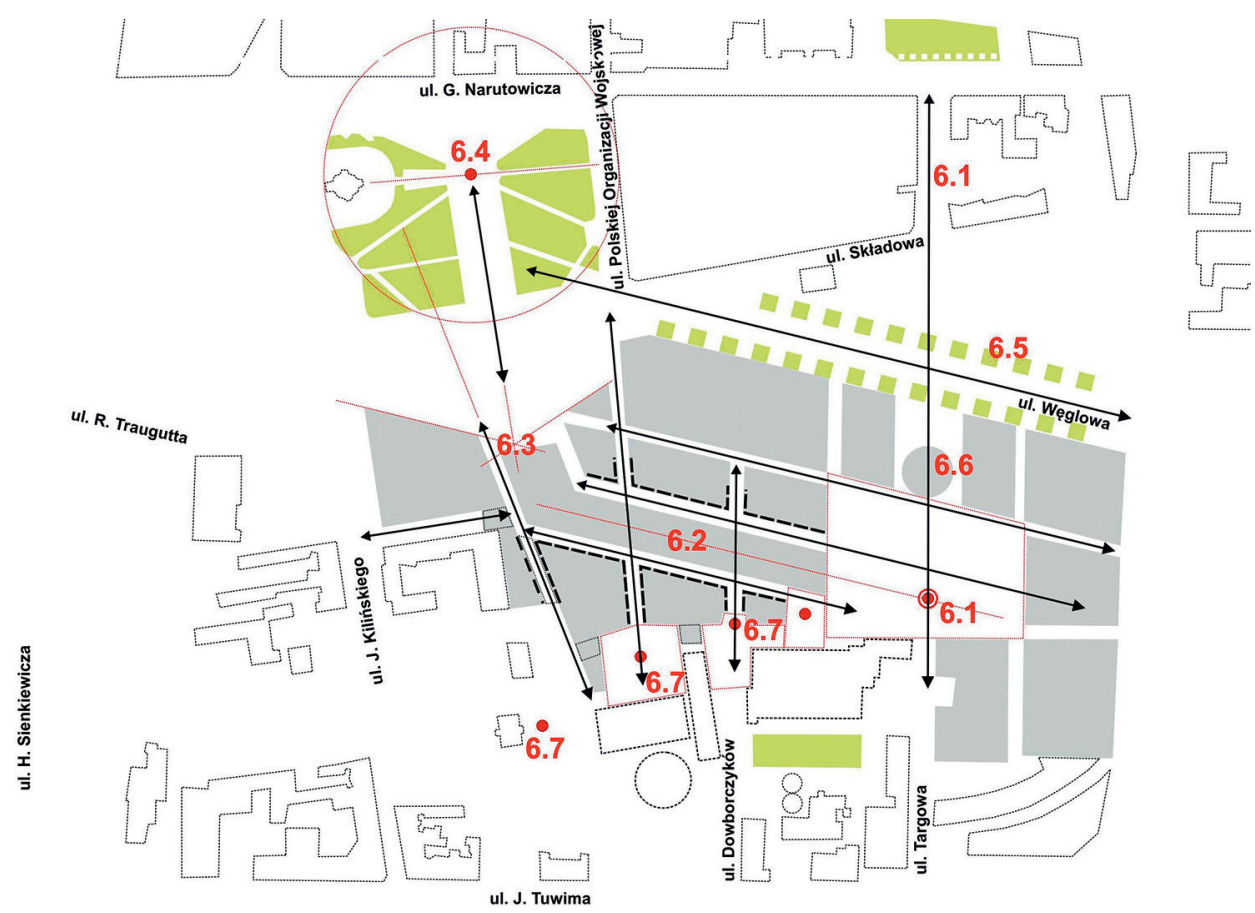

Rys. 5. Schemat graficzny dyspozycji przestrzennych dla Programu Nowe Centrum Łodzi Źródło: jak w rysunku 4. 
Dyspozycje przestrzenne zawierają rozwiązania przedstawione na rysunku 5:

- kontynuację osi ul. Knychalskiego wytyczającą oś symetrii projektowanego Rynku Kobro i zlokalizowany na nim akcent przestrzenny;

- liniowe założenie Specjalnej Strefy Sztuki o osi przecinającej się w punkcie akcentu przestrzennego Rynku Kobro;

- „otwarcie” Bramy Miasta, jako zamknięcie Specjalnej Strefy Sztuki, na park Moniuszki;

- akcent przestrzenny zlokalizowany w centralnej części parku Moniuszki, ustawiony na osiach parku i cerkwi św. Aleksandra Newskiego;

- budowę zielonego bulwaru w osi ul. Węglowej, łączącego się funkcjonalnie i kompozycyjnie z parkiem Moniuszki;

- budowę obiektu kubaturowego na osi ul. Knychalskiego w linii zabudowy ulicy zlokalizowanej pomiędzy ul. Węglową a projektowaną ul. Żydowską;

- sekwencję czterech akcentów urbanistycznych w przestrzeniach publicznych zlokalizowanych przy EC-1.

\section{Układ drogowy do Studium wykonalności zadania: Przebudowa dworca Lódź Fabryczna wraz z zagospodarowaniem terenu przyległego - 2009 r.}

Na podstawie Programu Nowe Centrum Łodzi w latach 2009-2010 konsorcjum firm SYSTRA, AREP, BBF wykonało studium wykonalności wraz z programem funkcjonalno-użytkowym, koncepcję koordynacyjną zagospodarowania terenu dworca Łódź Fabryczna, a także opracowało materiały do wniosku o dofinansowanie projektowanych przedsięwzięć z funduszy Unii Europejskiej.

Przebudowa dworca i układu drogowego miała na celu ożywienie społeczne i gospodarcze zdegradowanego rejonu centrum miasta, poprawę jego atrakcyjności w oczach turystów i inwestorów, a także zwiększenie znaczenia Łodzi jako ośrodka kultury. W jego rejonie znajdować się miały: stacja kolejowa (przeniesiona całkowicie pod ziemię), przystanki autobusów dalekobieżnych i miejskich, tramwajów oraz podziemne zaplecze parkingowo-usługowe. Kluczowe znaczenie dla rozwoju miasta będzie miało także projektowane przeprowadzenie przez nie linii kolei dużych prędkości zwanej „Y” (Warszawa-Łódź-Poznań, Warszawa-Łódź-Wrocław), które nada węzłowi Łódź Fabryczna charakter międzynarodowy (Plan sytuacyjny układu drogowego... 2009).

Plan sytuacyjny przebudowy układu drogowego przy dworcu Łódź Fabryczna wraz z zagospodarowaniem terenu przyległego, zawiera rozwiązania przedstawione na rysunku 6:

- kontynuację osi ul. Knychalskiego do projektowanego Rynku Kobro;

- budowę, w oparciu o oś ul. Knychalskiego, ulicy i symetrycznych przestrzeni publicznych pomiędzy ulicami Składową i Węglową, z obustronnymi przymknięciami;

- realizację Specjalnej Strefy Sztuki, wyznaczającej elementy detalu urbanistycznego na Rynku Kobro - tj. zejścia do parkingów podziemnych; 


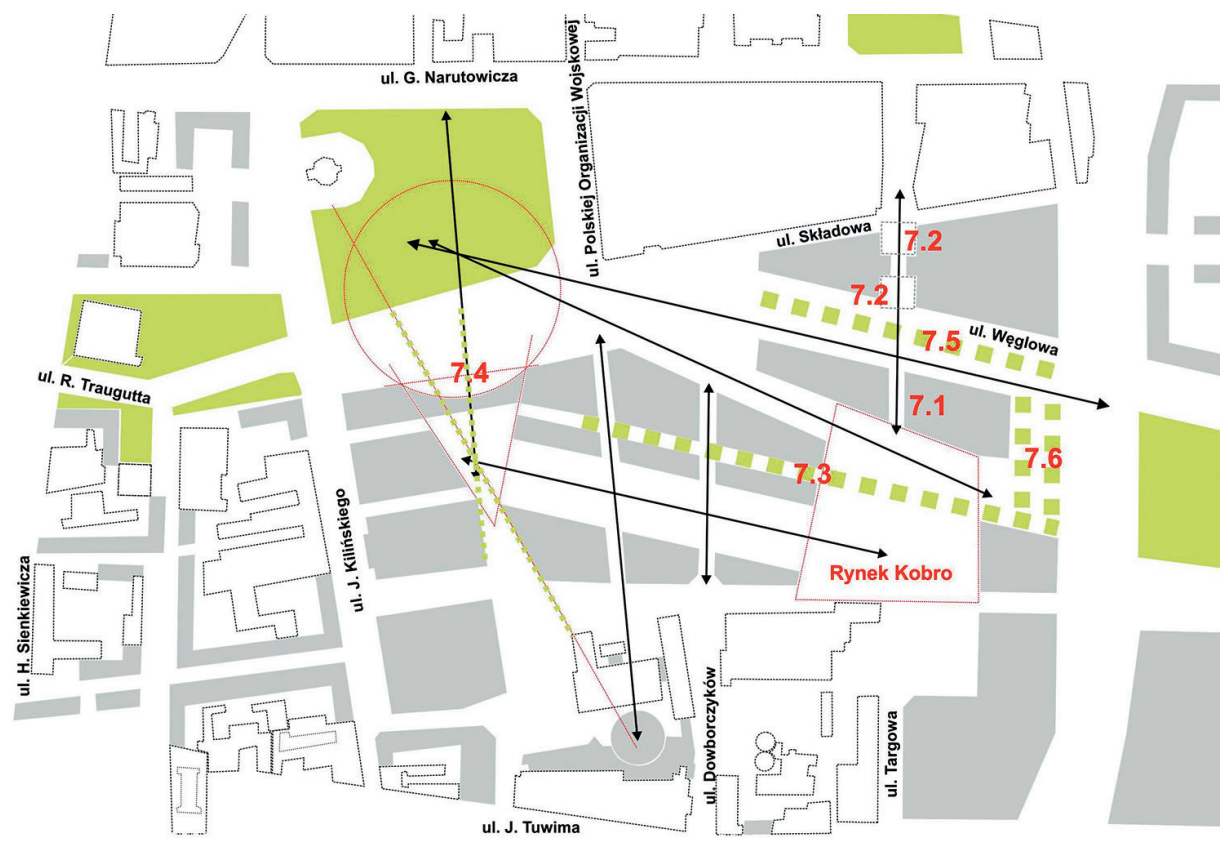

Rys. 6. Schemat graficzny planu sytuacyjnego przebudowy układu drogowego przy dworcu Łódź Fabryczna wraz z zagospodarowaniem terenu przyległego, konsorcjum SYSTRA, AREP, BBF

Źródło: jak w rysunku 4.

- „otwarcie” Bramy Miasta na park Moniuszki;

- uzupełnienie ul. Węglowej o ciąg zieleni;

- realizację ciągu zieleni zlokalizowanego pomiędzy ul. Węglową a projektowaną ul. Żydowską, będącego kontynuacją założenia parku 3 Maja.

\section{Studium Uwarunkowań i Kierunków Zagospodarowania Przestrzennego Miasta Lodzi - 2010 r.}

Zgodnie z dokumentem (Studium uwarunkowań... 2010) historyczny rozwój Łodzi jest ściśle związany z traktem piotrkowskim będącym podstawą dla lokalizacji ul. Piotrkowskiej, która stała się główną osią miasta i wyznaczała jego układ do końca XX w. Pod koniec ubiegłego wieku rozpoczął się proces tworzenia nowej osi krystalizującej układ przestrzenny miasta, na kierunku wschód-zachód. Podjęte działania realizacyjne oraz przyjęta wizja miasta przekształcają przestrzenny układ miasta na oparty na dwóch osiach kompozycyjnych:

- osi północ-południe - jako osi historycznej, opierającej się na ul. Piotrkowskiej i ukształtowanej wokół niej strefy centralnej, stanowiących o tożsamości przestrzennej miasta; 
- osi wschód-zachód - jako współczesnej osi koncentrującej głównie program usługowy na odcinku kolei obwodowej.

Dodatkowym elementem układu jest program oparty na przebudowie systemu kolejowego wraz z podziemnym dworcem i tunelem średnicowym przez śródmieście. Pozwala on na utworzenie multimodalnych centrów komunikacyjnych w oparciu o dworce Łódź Kaliska i Łódź Fabryczna wraz z portem lotniczym im. Władysława Reymonta podłączonym do układu kolejowego. W konsekwencji Studium uznaje za podstawowe elementy krystalizujące układ przestrzenny miasta:

- oś historyczną tożsamości miasta północ-południe, wytworzoną w oparciu o ul. Piotrkowską;

- oś współczesną wschód-zachód, ze szczególną kulminacją w części śródmiejskiej;

- Nowe Centrum Łodzi - obejmujące wszystkie jego elementy programowe i przestrzenne, a w szczególności rejon ul. Piotrkowskiej, miasto kultury, biznesu i dworzec multimodalny;

- Zielony Krąg Tradycji i Kultury - wyznaczający obszar centralny miasta i łączący system parków i innych form zieleni urządzonej oraz obiektów i terenów świadczących o tożsamości Łodzi.

Należy przy tym zauważyć, że w Studium wskazano oś kompozycyjną parku Moniuszki i zbudowanego na jej przedłużeniu placu jako jeden z głównych ciągów pieszych i placów miasta.

\section{Uchwała Rady Miejskiej w Lodzi zmieniająca uchwałę w sprawie przyjęcia Programu Nowe Centrum Łodzi - 2012 r.}

W uchwale tej w wymiarze urbanistycznym najistotniejszymi modyfikacjami były zmiana obszaru i wielkości opracowania oraz podział na nowe strefy.

Program Nowe Centrum został ograniczony ulicami: Tuwima, Narutowicza, Piotrkowską oraz Kopcińskiego i obejmuje powierzchnię ok. 100 ha. Teren ten podzielony został na trzy strefy (Uchwała XLV/840/12... 2007):

- Strefa I (ok. 40 ha), w której toczyć się będzie całodobowe życie dzięki zrównoważonemu rozwojowi funkcji kulturalnych, komercyjnych i mieszkaniowych. Tym celom służyć ma realizacja projektów: Rewitalizacja EC-1 i jej adaptacja na cele kulturalno-artystyczne i Specjalna Strefa Kultury. Miasto ma podjąć również działania mające na celu analizę możliwości realizacji innych projektów na tym obszarze, takich jak: rynek, Brama Miasta, centrum kongresowe. Głównym czynnikiem zmian urbanistycznych i społecznych w tym obszarze jest przebudowa dworca Łódź Fabryczna wraz z węzłem multimodalnym i nowym układem komunikacyjnym.

- Strefa II (ok. 30 ha), w której powinny być realizowane przedsięwzięcia komercyjne z uwzględnieniem programów rewitalizacyjnych, mających na celu zachowanie historycznej tkanki miejskiej. 
- Strefa III (ok. 30 ha) - to obszar gęstej zabudowy historycznej z przełomu XIX i XX w. w postaci kwartałów wielkomiejskich wymagających intensywnej rewitalizacji i uzupełnień.

Ponadto ustalono dla nowo określonej strefy I rozwiązania przestrzenne będące syntezą dyspozycji przestrzennej autorstwa Kriera oraz wyników warsztatów „Zszywanie Miasta” zorganizowanych w 2011 r. przez Miejską Pracownię Urbanistyczną w Łodzi wraz z Łódzkim Oddziałem Towarzystwa Urbanistów Polskich dla obszaru opracowania. Ostateczne i szczegółowe rozwiązania urbanistyczne dla tego obszaru miały zostać określone w miejscowych planach zagospodarowania przestrzennego opracowanych dla tego obszaru.

W ustaleniach w zakresie zagospodarowania terenu przy dworcu Łódź Fabryczna i terenu przyległego za szczególne widoczne uważano elementy przedstawione na rysunku 7:

- osiowe rozwiązanie obiektów związanych ze Specjalną Strefą Sztuki oraz towarzyszącym im przekryć przestrzeni publicznych w oparciu o oś ul. Traugutta;

- „otwarcie” Bramy Miasta w kierunku budynku z Galerią Forum Fotografii.

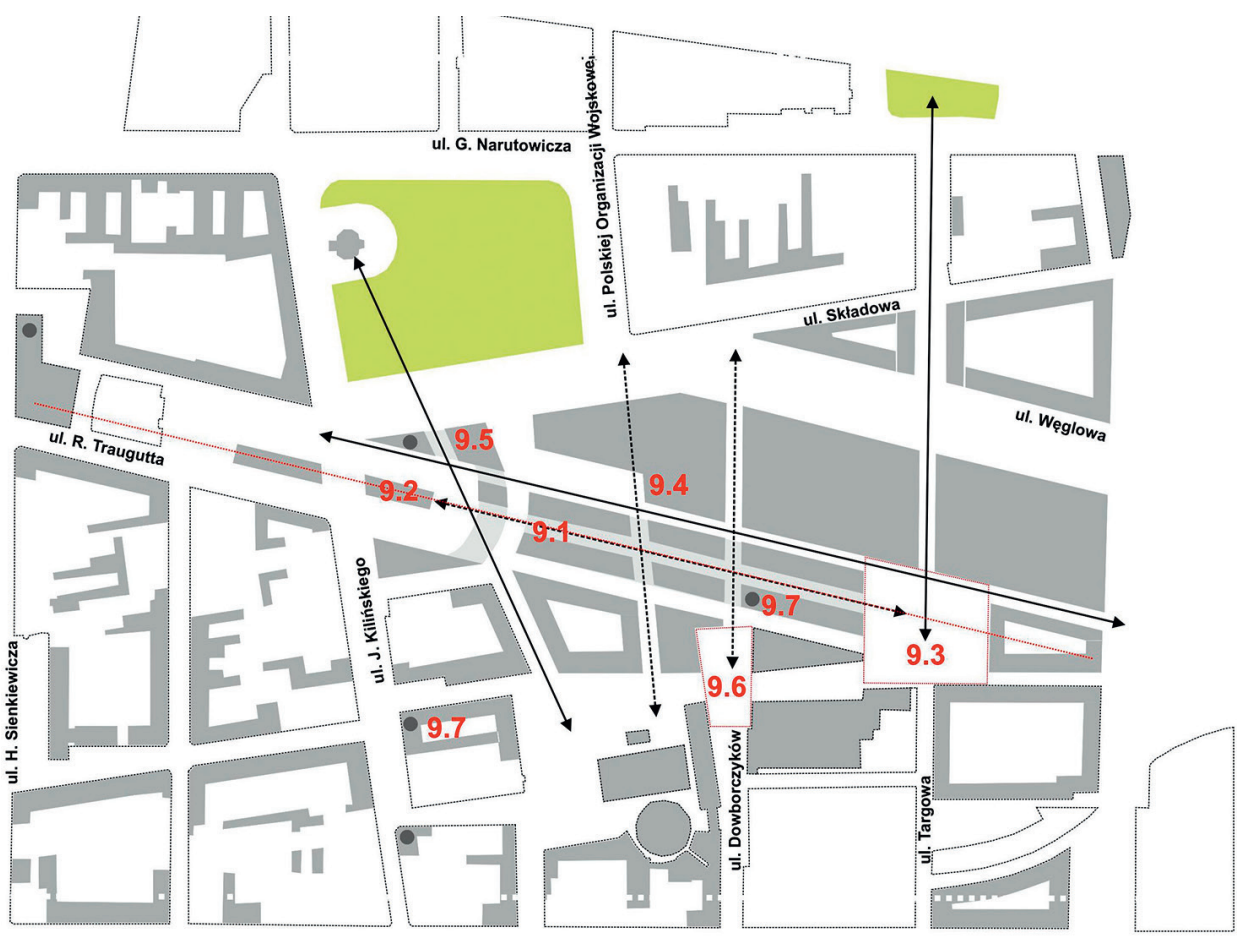

ul. J. Tuwima

Rys. 7. Schemat graficzny syntezy rozwiązań przestrzennych dyspozycji przestrzennej autorstwa Roba Kriera oraz wyników warsztatów „Zszywanie Miasta”

Źródło: jak w rysunku 4. 
Dodatkowo przyjęto rozwiązania:

- kontynuacji osi ul. Knychalskiego, wytyczającej oś symetrii projektowanego Rynku Kobro;

- wykorzystanie osi ulic: Polskiej Organizacji Wojskowej w kierunku obiektów elektrowni EC-1 zachód i Dowborczyków, dzielących obiekt Specjalnej Strefy Sztuki;

- wytyczającej podział na kwartały oraz nadwieszenie w okolicy Bramy Miasta osi na kierunku: cerkiew św. Aleksandra Newskiego - EC-1 zachód;

- wytyczenia trapezowej przestrzeni publicznej pomiędzy EC-1 wschód i zachód;

- lokalizacji dominant przestrzennych w wybranych kwartałach.

\section{Projekt planu dla części obszaru miasta Łodzi położonej w rejonie ulic: Prezydenta G. Narutowicza, W. Lindleya, Wodnej, J. Tuwima i H. Sienkiewicza - 2014 r.}

Zgodnie z przytoczoną wyżej uchwałą z 2012 r. szczegółowe rozwiązania dla tego obszaru zostały określone w koncepcji, a następnie w miejscowych planach zagospodarowania przestrzennego.

W Projekcie Miejscowego Planu Zagospodarowania Przestrzennego dla części obszaru miasta Łodzi położonej w rejonie ulic: Prezydenta G. Narutowicza, W. Lindleya, Wodnej, J. Tuwima i H. Sienkiewicza (2014) zaznaczono główne osie przyjętych rozwiązań (rysunek 8), którymi są m.in.:

- osiowe umiejscowienie obiektów związanych ze Specjalną Strefą Sztuki oraz towarzyszących im przestrzeni publicznych w oparciu o przełamaną oś ul. Traugutta;

- forma obiektu Bramy Miasta dynamicznie skierowana w stronę budynku z Galerią Forum Fotografii i ul. Piotrkowskiej;

- realizacja obiektów na osi równoległej do linii zabudowy ul. Węglowej.

Ponadto przyjęto rozwiązania:

- kontynuacji osi ul. Knychalskiego wytyczającej kierunek powiązań komunikacji pieszej i rowerowej oraz kompozycyjnych, przylegający do wschodniej pierzei Rynku Kobro;

- wykorzystania osi ulic: Polskiej Organizacji Wojskowej i Dowborczyków, dzielących obiekt Specjalnej Strefy Sztuki;

- wytyczenia przestrzeni publicznej otwartej na park Moniuszki „opartej” o Bramę Miasta;

- wytyczenie ciągu ul. Traugutta jako kierunku powiązań komunikacji pieszej i rowerowej oraz kompozycyjnych z ul. Piotrkowską.

\section{Podsumowanie}

Analizując ewolucję koncepcji i założeń kompozycyjnych przekształceń obszaru Nowego Centrum Łodzi, począwszy od masterplanu Kriera z 2007 r. po projekt miej- 


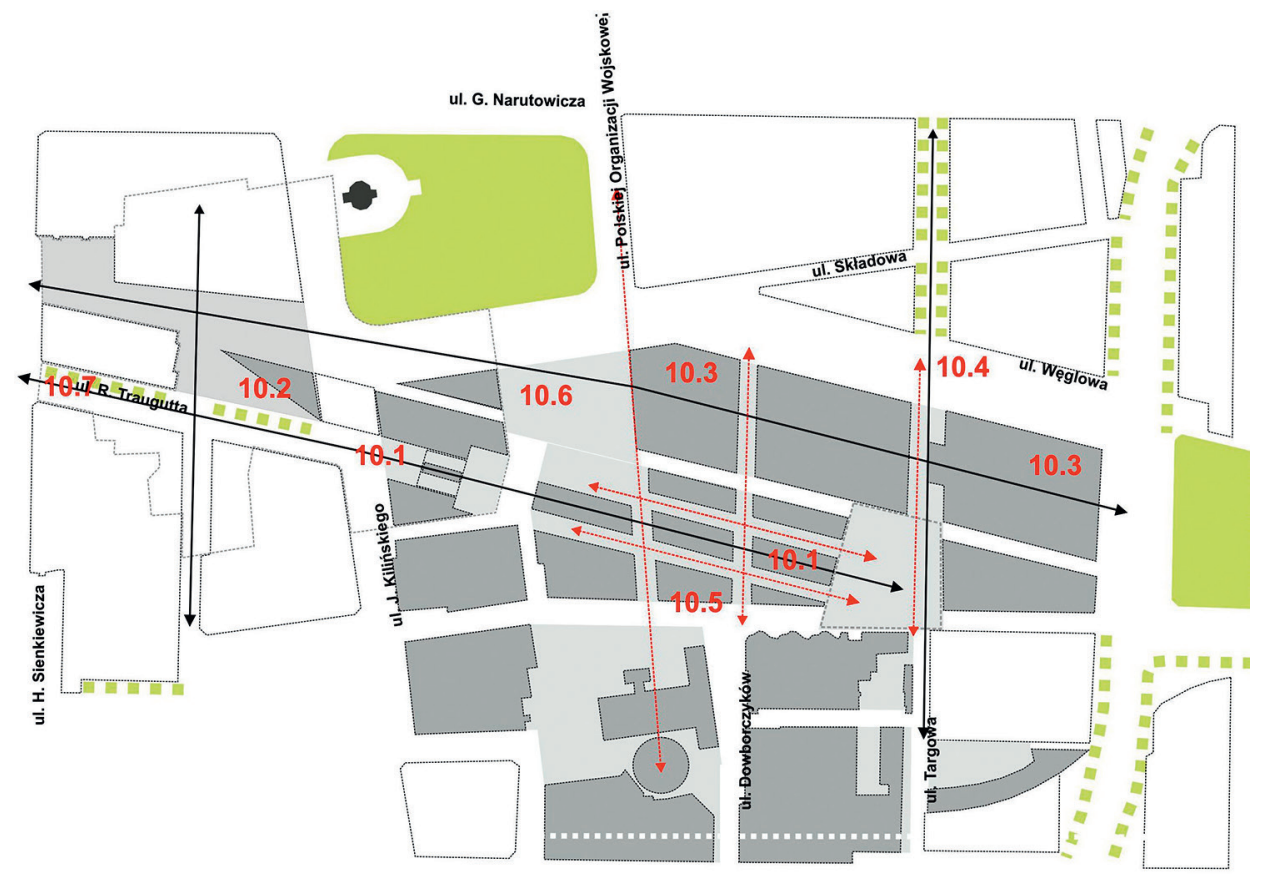

ul. J. Tuwima

Rys. 8. Schemat graficzny projektu miejscowego planu zagospodarowania przestrzennego dla części obszaru miasta Łodzi położonej w rejonie ulic: Narutowicza, Lindleya, Wodnej, Tuwima i Sienkiewicza

Źródło: jak w rysunku 4.

scowego planu zagospodarowania przestrzennego dla tej części miasta opracowanego przez Miejską Pracownię Urbanistyczną z Łodzi z roku 2014, należy wyróżnić zakresy głównych i drugoplanowych rozwiązań funkcjonalnych i kompozycyjnych.

W zakresie kompozycji urbanistycznej kolejnym planom towarzyszyły następujące zmiany:

- W Programie Nowego Centrum Łodzi z 2007 r., uchwalonego na podstawie pierwotnego masterplanu Kriera, główne założenia funkcjonalne i formalne zachowano, przy czym przyjęto inne od charakterystycznego dla Kriera geometrycznego rozwiązania osi ul. Knychalskiego jak również zmieniono planowaną wielkość Rynku Kobro. Pominięto założenia funkcjonalne i kompozycyjne rozwiązań zlokalizowanych poza przyjętą w uchwale strefą 1 .

- W opracowaniu układu drogowego dla zadania przebudowy dworca Łódź Fabryczna wraz z zagospodarowaniem terenu przyległego, wykonanego przez konsorcjum firm SYSTRA, AREP, BBF, nastąpiła zmiana geometrii Rynku Kobro oraz przyjęto nowe rozwiązanie przecięcia rynku ciągiem zieleni łączącym park 3 Maja z Bramą Miasta. Zrezygnowano z sekwencji przestrzeni publicznych w bezpośrednim otoczeniu EC-1 w zamian za wyrównaną linię zabudowy sąsiadujących kwartałów. Po wschodniej 
stronie EC-1 wschód zaproponowano nieistniejącą we wcześniejszych planach formę małego placu. Zmieniono również lokalizację centrum festiwalowo-kongresowego. Spowodowało to znaczną utratę zwartości układu kompozycyjnego planowanego zespołu urbanistycznego.

- W uchwale z 2012 r. zmieniającej uchwałę w sprawie przyjęcia Programu Nowe Centrum Łodzi z 2007 r. wykonano syntezę rozwiązań przestrzennych masterplanu Kriera oraz warsztatów „Zszywanie Miasta”. Jej najistotniejszą zmianą w stosunku do wcześniej przyjętych rozwiązań przestrzennych jest rezygnacja z kierunku osi cerkwi św. Aleksandra Newskiego i osi parku Moniuszki ustalających kierunek „otwarcia” Bramy Miasta - na korzyść krótkiej w swoim przebiegu osi od ul. Sienkiewicza ul. Traugutta, ustanowionej jako oś Bramy Miasta, Specjalnej Strefy Sztuki i struktury przestrzennej obszaru.

- W Projekcie Miejscowego Planu Zagospodarowania Przestrzennego dla części obszaru miasta Łodzi położonej w rejonie ulic: Prezydenta G. Narutowicza, W. Lindleya, Wodnej, J. Tuwima i H. Sienkiewicza przyjęto rozwiązanie Bramy Miasta dynamicznie ustawionej w kierunku centrum związanego z ul. Piotrkowską, z jej jednoczesnym nadwieszeniem nad ul. Kilińskiego. Oba rozwiązania nie istnieją w pierwotnych założeniach Kriera. Zwracają uwagę również: zmiana z proponowanych w masterplanie rozwiązań przestrzeni publicznej na osi ul. Knychalskiego, zmniejszenie Rynku Kobro i rezygnacja z osi kompozycyjnej wychodzącej w komina chłodni EC-1.

W zakresie założeń funkcjonalnych niezmienne pozostały:

- przeniesienie dworca kolejowego Łódź Fabryczna pod ziemię;

- utworzenie Specjalnej Strefy Kultury;

- adaptacja obiektów EC-1 na cele kulturalne (realizowana).

Funkcje kulturalne (centrum festiwalowo-kongresowe, Specjalna Strefa Sztuki) zostały zmienione na funkcje komercyjne - usługowe i mieszkaniowe. Zmianom uległy również pierwotne założenia kompozycyjne: Bramy Miasta, Rynku Kobro i osi ul. Knychalskiego, które realizowane są według zmienionych rozwiązań urbanistycznych. Odpowiednio:

- Brama Miasta - pierwotnie otwierając się na park Moniuszki, została odwrócona w kierunku ul. Piotrkowskiej.

- Rynek Kobro o pierwotnej wyrazistej formie geometrycznej, zbudowanej na osiowym założeniu wzdłuż ul. Knychalskiego, został przesunięty i pomniejszony.

- Znaczenie osi ul. Knychalskiego zostało wyraźnie zmniejszone, a jej oprawa zubożona.

W ocenie autora główne założenia funkcjonalne i formalne w widoczny sposób już wpływają i wpłyną w przyszłości na polepszenie funkcjonowania tego obszaru i wzrost jego znaczenia dla całego miasta Łodzi. Rysunek 9 przedstawia realizację przebudowy dworca Łódź Fabryczna.

$\mathrm{Na}$ uwagę zasługują również proces przebudowy i rewitalizacji centrum miasta i dyskusja nad nimi, trwające 10 lat dochodzenie do rozwiązań formalnych i funkcjonalnych - rozpoczęte koncepcją urbanistyczną dla zdegradowanego Śródmieścia Łodzi 


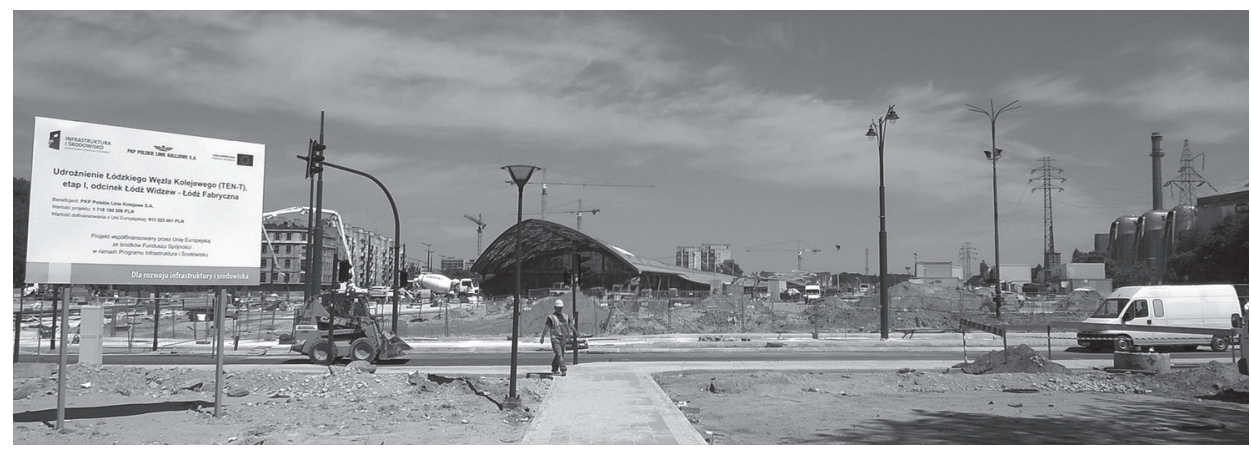

Rys. 9. Dworzec Łódź Fabryczna w trakcie realizacji

Źródło: fot. S. Opania, maj 2016.

opracowaną w 2007 r. przez Kriera, zwaną w następnych latach masterplanem Kriera, przez kolejne opracowania rozwiązań systemu komunikacyjnego, a zakończone zapisami w miejscowym planie zagospodarowania przestrzennego. Jest to proces zbieżny z podobnymi, modelowymi rozwiązaniami europejskimi lat 90., rozpoczynającymi się również wstępnymi koncepcjami, wyłanianymi jednak w drodze dużych konkursów urbanistycznych. Konkursów, w których dodatkową nagrodą są realizacje zwycięskich koncepcji zapewniające ich zbieżność z końcowymi rozwiązaniami projektowymi.

Wielość takich koncepcji powoduje, że Philip Jodido postrzega lata 90. ubiegłego wieku właśnie przez pryzmat rozwoju komunikacji i systemów komunikacji, które stały się istotnym czynnikiem rozwoju, wspieranym przez administracje rządowe i samorządowe w większości państw europejskich. Konsekwencją tego był wzrost znaczenia i jakości projektów urbanistyczno-architektonicznych dotyczących tej kategorii ${ }^{2}$.

Realizacja trwa i na pełne jej efekty należy poczekać. Podobnie jak na odpowiedź, czy Łódź ma szansę stać się symbolem dobrej rewitalizacji, przedyskutowanej, spełniającej nadzieje i oczekiwania mieszkańców.

\section{Bibliografia}

Jodido Ph., 1995, Contemporary European architects, vol. 3, Taschen Verlag, Köln.

Krier R., 1979, Urban space, Academy Editions, London.

Krier R., Kohl Ch., 2007, Lodz Concept Masterplan, 21.08.2007, Berlin.

Plan sytuacyjny układu drogowego do Studium wykonalności zadania: „Przebudowa dworca Łódź Fabryczna wraz z zagospodarowaniem terenu przyległego", 2009, konsorcjum firm SYSTRA, AREP, BBF, rys. nr A645-SW-D-RYS-00001-3.

2 Warto zauważyć, że Philip Jodido okres architektury europejskiej lat 90. oznaczył jako les utopies pragmatiques - czas ze snu architekta, w którym idee, wręcz niemożliwe do zrealizowania mrzonki, dzięki pragmatycznej postawie, opartej na realistycznej ocenie rzeczywistości i liczeniu się z konkretnymi możliwościami, stają się realne i skuteczne. Por. Jodido 1995, s. 6-11. 
Projekt Miejscowego Planu Zagospodarowania Przestrzennego dla części obszaru miasta Łodzi położonej w rejonie ulic: Prezydenta G. Narutowicza, W. Lindleya, Wodnej, J. Tuwima i H. Sienkiewicza, opracowanego przez Miejską Pracownię Urbanistyczną, Obwieszczenie o wyłożeniu do publicznego wglądu projektów miejscowych planów zagospodarowania przestrzennego, z dnia 16 czerwca $2014 \mathrm{r}$.

Studium uwarunkowań i kierunków zagospodarowania przestrzennego miasta Łodzi, 2010, http://www.mpu. lodz.pl/page/511,studium.html?id=7 (dostęp 1 czerwca 2017).

Uchwała Nr XVII/279/07 Rady Miejskiej w Łodzi w sprawie przyjęcia Programu Nowe Centrum Łodzi $\mathrm{z}$ dnia 28.08.2007 r.

Uchwała Nr XCIX/1826/10 Rady Miejskiej w Łodzi w sprawie uchwalenia Studium uwarunkowań i kierunków zagospodarowania przestrzennego miasta Łodzi, z dnia 27 października 2010 r.

Uchwała Nr XXXIV/568/04 Rady Miejskiej w Łodzi w sprawie przyjęcia Uproszczonego Lokalnego Programu Rewitalizacji wybranych terenów śródmiejskich oraz pofabrycznych Łodzi na lata 2004-2013, z dnia 14 lipca $2004 \mathrm{r}$.

Uchwała Nr XLV/840/12 Rady Miejskiej w Łodzi zmieniająca uchwałę w sprawie przyjęcia Programu Nowe Centrum Łodzi, z dnia 4 lipca 2012 r. 